\title{
Donkeys in the Old and Middle Kingdoms According to the Representations and Livestock Counts from Private Tombs
}

\author{
MiRAL LASHIEN
}

\begin{abstract}
The Egyptian artist in the Old and Middle Kingdoms showed great interest in representing the details of the physical characteristics and behaviour of various animals surrounding him in the Egyptian environment. However, donkeys seem to have received less attention from the artist than other animals. The paper examines the representations of donkeys in the wall scenes of the Old and Middle Kingdom tombs, and analyses the changing interest in reflecting this animal's physical traits and behaviour. Finally, studying the role of donkeys in the so-called livestock counts allows us to better understand the phenomenon which is observed in the iconographic sources from the period under investigation.
\end{abstract}

Keywords: donkey, Old Kingdom Egypt, Middle Kingdom Egypt, livestock count, Meir, Beni Hassan, Somali wild ass

Miral Lashien, Ministry of Tourism and Antiquities, Egypt, Cairo; miralzakarialashien@gmail.com; (D) 0000-0003-3935-3076

An examination of scenes from the walls of private tombs of the Old and Middle Kingdoms reveals that the artists, or at least some of them, had intimate knowledge of the natural world surrounding them. A close look at the animals represented there demonstrates artists' detailed familiarity with an unusually large number of different species of mammals and birds. Not only is the shape of each animal correctly drawn, but the colours of skin or feathers covering different parts of their bodies are accurately rendered, so much so that in most cases we are able to easily identify the different species with certainty. A clear case with which to demonstrate this point can be the depiction of birds in the tomb of Khnumhotep II at Beni Hassan. ${ }^{1}$ While birds are drawn accurately in many other tombs from all Egyptian periods and sites, ${ }^{2}$ such abundance of detail in their colours as found in Khnumhotep II's tomb is remarkable.

\footnotetext{
${ }^{1}$ Newberry 1893a: Pls 30, 33-34; Kanawati, Woods 2010: Photographs 16, 19-20, 24, 190-203; Kanawati, Evans 2014a: Pls 67, 70-73, 133, 137.

${ }^{2}$ For different bird species in Ancient Egypt, see: Houlihan 1986.
} 
With regard to the representation of the donkey in private tombs, it is clear that this animal did not receive particular attention from artists, ${ }^{3}$ who represented its physical features and different characteristics in fewer details than is usual for other animals. Furthermore, wall scenes exhibit an explicit interest in the life of animals, frequently showing mating, giving birth assisted by a herdsman, grazing, crossing a body of water, being led out of marshlands, being tended to by a herdsman, and even occasional grooming gestures. ${ }^{4}$ It is surprising then that these activities are almost not shown in the case of donkeys, ${ }^{5}$ which are also rarely depicted in most of the scenes of the presentation of animals, including oxen and less frequently goats and desert animals, to the tomb owner. All of this draws our attention to a noteworthy question: Was the donkey one of the less important animals for the Egyptians? It is noticed that the appearance of this animal was mainly restricted during the Old Kingdom to its participation in activities related to agricultural pursuits. Thus donkeys are shown transporting the harvested crop to the threshing floor, or returning from there to the field. Like oxen, and rarely sheep, ${ }^{6}$ packs of donkeys are frequently used to tread the harvested sheaves in order to separate the grain from the hay. In rare instances, as in the tombs of Werkhewew at $\mathrm{Giza}^{7}$ and Niankhkhnum and Khnumhotep at Saqqara, ${ }^{8}$ dated to the Fifth Dynasty, ${ }^{9}$ the donkey was also used for transporting the tomb owner, who appears on a litter tied to the backs of two animals. Using donkeys as means of transportation is also attested on Middle Kingdom stelae from Serabit el-Khadim in Sinai. ${ }^{10}$ The aim of this paper is to examine the significance of donkeys for the Egyptians during the Old and Middle Kingdoms, as evident in their representations in the art and their role in livestock count of these periods.

\section{THE REPRESENTATIONS OF DONKEYS}

While representations of donkeys during a large part of the Old Kingdom focused on their role in agricultural pursuits, with rare attention to other aspects of their characteristics and life cycle as well as their physical appearance, the evidence seems to show that the depiction of these aspects became more conspicuous as time progressed. In the mastabas of Tjy and Mereruka at Saqqara and Seshemnefer IV at Giza, ${ }^{11}$ all dated to the late Fifth Dynasty

\footnotetext{
3 For donkeys in Ancient Egypt, see: Power 2004: 131-151; Closse 1998: 27-39.

${ }^{4}$ For an extensive study of different animal behaviour in tomb wall scenes, see: Evans 2010; for grooming gestures, see: Evans 2010: 75f.; for clear examples of animal grooming, see: Blackman 1914: Pl. 11; Kanawati 2012: Pls 41(b), 84; Kanawati, Abder-Raziq 2003: P1. 44(b).

5 Among rare instances of the Old Kingdom representations of mating wild asses, one should enumerate scenes from the Sun temple of Niuserre (Edel, Wenig 1974: P1. 17, no. 725), and the tomb of Nimaatre at Giza (Roth 1995: P1. 189).

6 See, for example: Duell 1938: P1. 169; Kanawati et al. 2011: P1. 83.

7 Hassan 1944: Fig. 104

8 Moussa, Altenmüller 1977: Pls 42-43.

9 Harpur 1987: 268 [180]; Moussa, Altenmüller 1977: 44-45.

10 Gardiner, Peet 1952: Pls 37, 39, 85; 1955: 114, 119, 206, Fig. 17. See also: Smith 1965: 110, Fig. 47.

11 Wild 1966: Pl. 154; Duell 1938: Pl. 169; Kanawati et al. 2011: Pl. 82; Junker 1953: Fig. 75.
} 

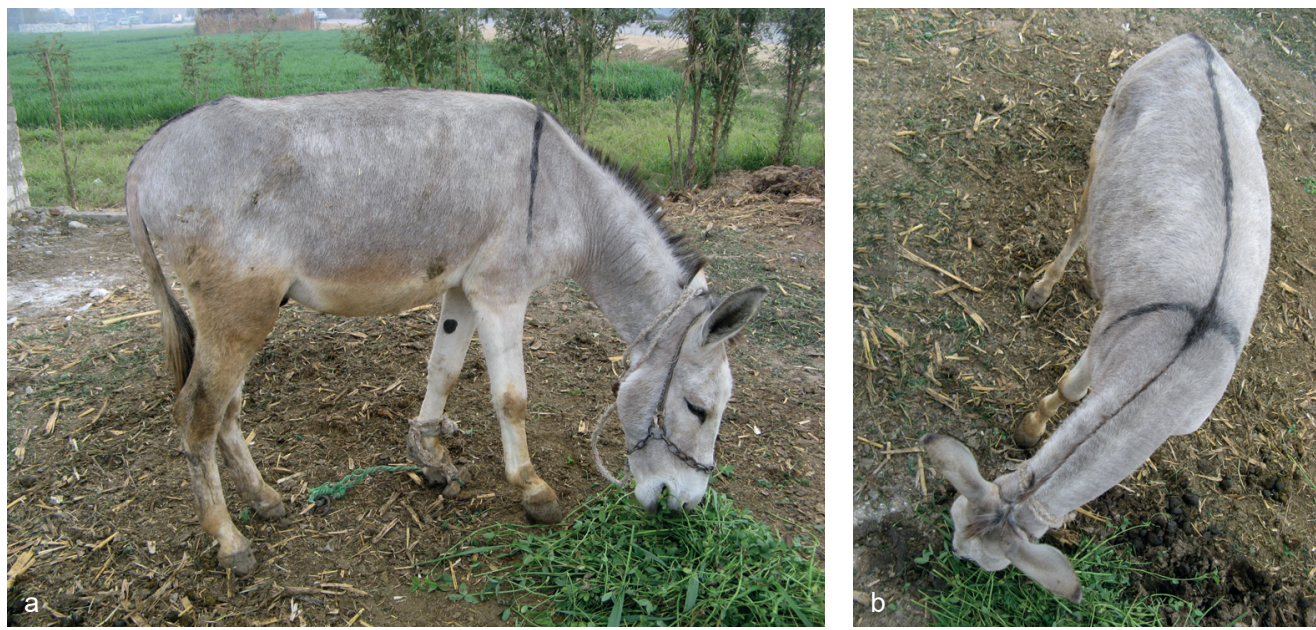

1. Donkey with the chestnut as well as shoulder and dorsal stripes (Phot. from the archive of M. Lashien).

to the early Sixth Dynasty, ${ }^{12}$ as well as in other tombs, ${ }^{13}$ a farmhand is shown holding an unyielding donkey by one leg and one ear in an attempt to render it motionless, ${ }^{14}$ which demonstrates the Egyptian understanding of the behavioural traits of his animal and how to deal with them. In Tjy's tomb a small donkey walks in front of its mother to entice the latter to move. Furthermore, the artist demonstrated his familiarity with the physical details of the animal's body by regularly showing the chestnut on the inner side of the foreleg, above the knee. ${ }^{15}$ The chestnut (Fig. 1a), also known as a night eye, is a dark 'elongated horny outgrowth of the skin ${ }^{16}$ which is found on the forelegs of donkeys and horses, and the latter also have it on the hind legs. Its shape and size vary and are subject to changes over time. ${ }^{17}$ One of the features differentiating races of assess is the dark shoulder stripes. ${ }^{18}$ The shoulder and dorsal stripes resemble a 'cross' marking on the back and shoulders of the animal (Fig. 1a-b) ${ }^{19}$ and this characteristic is also drawn by Tjy's artist. ${ }^{20}$ The chestnut and the cross are occasionally observed by artists, as we see in the tomb of Pepyankh the middle of Meir (early Pepy II). ${ }^{21}$ However, the artist of Pepyankh the middle curiously drew

${ }^{12}$ For the dating, see: Harpur 1987: 270 [235], 274 [420], 277 [543].

${ }_{13}$ Hassan 1932: Fig. 26; Mohr 1943: Fig. 50.

${ }^{14}$ Kanawati 2007: 69, Fig. 150.

15 See: Wild 1966: Pl. 154.

16 Clutton-Brock 1992: 18.

17 Evans et al. 1990: 80; Clutton-Brock 1992: 18-19.

18 See: Clutton-Brock 1992: 27-36.

19 Yilmaz 2012: 28; Clutton-Brock 1992: 27-36, Fig. 2.18; Makowski 2014: 270-271.

${ }^{20}$ Wild 1966: Pl. 154.

${ }^{21}$ For the dating of Pepyankh the middle's tomb, see: Kanawati, McFarlane 1992: 300; Kanawati 2010: 217; 2012: 24-26; Lashien 2017: 44ff., 220. 


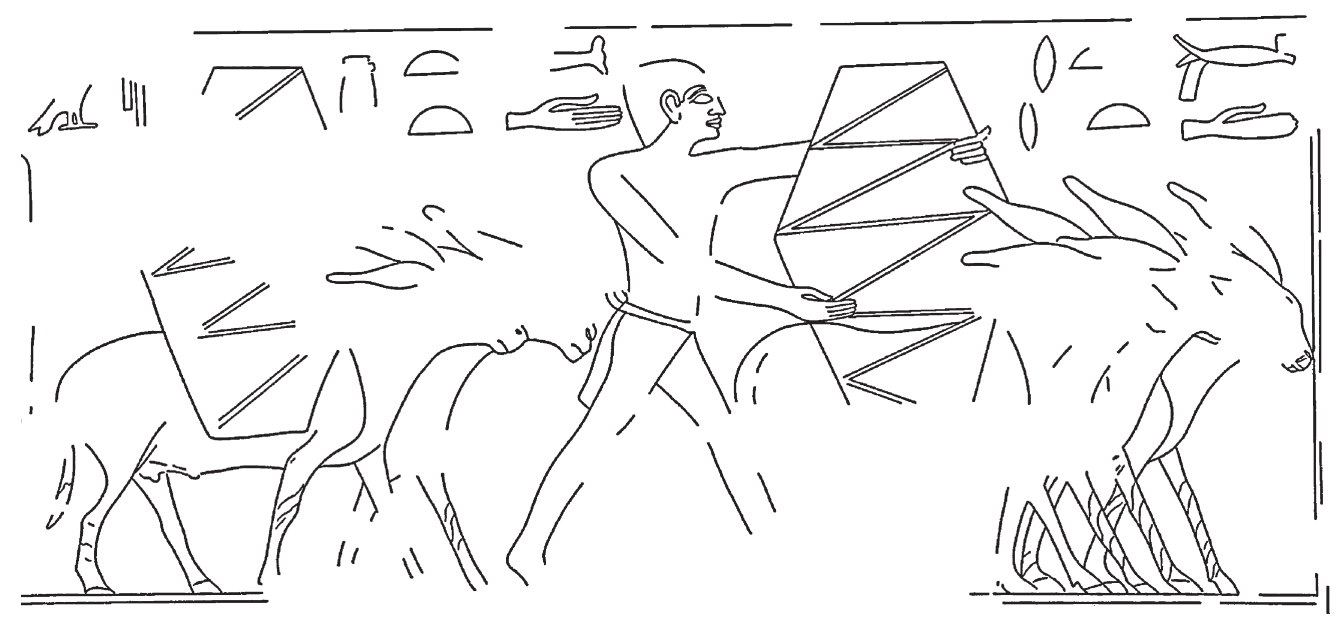

2. Somali wild asses represented in the tomb of Pepyankh the middle (Meir), west wall (Courtesy of The Australian Centre for Egyptology).

a black spot on the lower part of the animal's neck. ${ }^{22}$ This marking, which is known as 'collar buttons', is small and circular spots of dark hair found on the neck of some donkeys. ${ }^{23}$

Also, in the tomb of Pepyankh the middle we find the most unusual representation of donkeys, where the animals' legs are painted with clear black oblique stripes, resembling those of zebras (Fig. 2).$^{24}$ At first this may appear as a mistake by the artist, yet it has been determined that these are very specific characteristic of certain subspecies of the African wild ass, the Somali wild ass (Equus africanus somaliensis) (Fig. 3). This animal is somewhat larger and stronger than domestic asses and has small, short legs and long ears. It can travel for long distances and survive on little water and reduced food. The animal is known from North Africa, Eritrea, Ethiopia and Somalia, with an uncertain presence in Djibouti, Egypt and Sudan..$^{25}$ The careful representation of the African/Somali wild ass by Pepyankh the middle's artist leaves little doubt that it was known in Old Kingdom Egypt, although was probably not common. The absence of such a species of donkey in other Old and Middle Kingdom tombs is noteworthy, ${ }^{26}$ and may indicate its rarity, but also emphasises the perceptiveness of the artist who decorated the tomb of Pepyankh the middle. It should be noticed that this species is not depicted even in the tombs of Niankhpepy the black and

22 Blackman 1924: Pls 14, 22(2); Kanawati 2012: Pls 46(b), 47(a), 84.

${ }_{23}$ Yilmaz 2012: 30, Fig. 15; see also 'collar buttons' on the web-pages: Mini Donkey Terms Glossary; All about Donkeys.

${ }_{24}$ Blackman 1924: Pls 14, 22/2; Kanawati 2012: Pl. 84.

${ }^{25}$ Clutton-Brock 1992: 19, 23, 27-36, 62-63; 1999: 116-118, Fig. 10.6; 2012: 57. For more biogeographical information about wild asses and donkeys in Africa, see: Blench 2013: 1-14; for equids in Ancient Egypt, see: Clutton-Brock 1992: 80ff.

${ }^{26}$ On site examination of the representations of this animal in many other cemeteries failed to produce any trace of a similar example. 


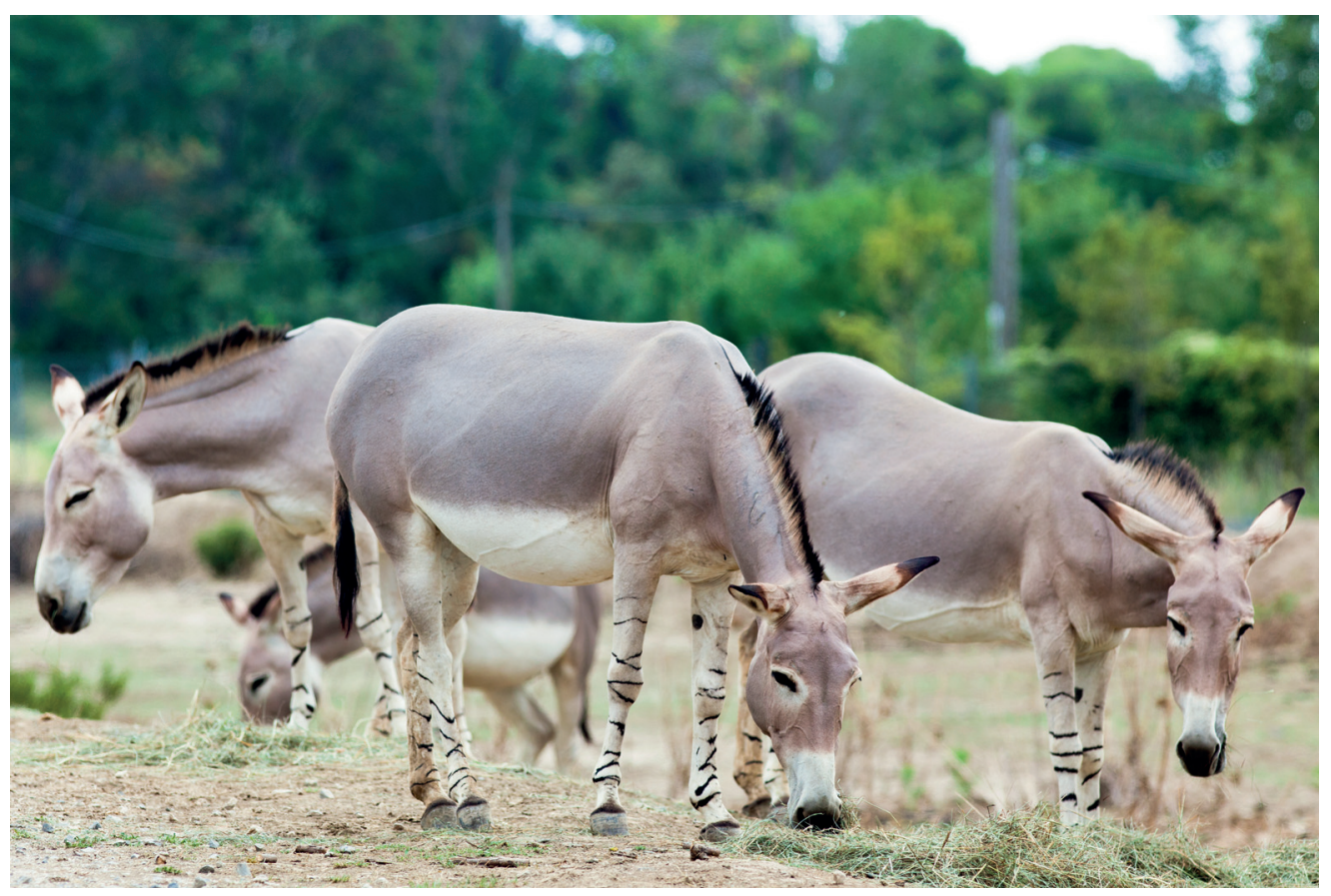

3. Somali wild ass (Equus africanus somaliensis) (CiStock.com/Ostill; Photo ID: iStock-119689563).

Pepyankh the black, the son and grandson of Pepyankh the middle. ${ }^{27}$ Its presence in the latter's tomb may be related to his unique post as 'overseer of Upper Egypt in the middle provinces ${ }^{28}$ (see below) and the need for efficient transportation in the unusually large area under his jurisdiction, hence the possible import of this rather strong animal from a neighbouring region.

A representation in the tomb of Mery at El-Hagarsa, dated to the second half of Pepy II's reign, ${ }^{29}$ shows a male donkey attempting to mount a female, curiously facing the wrong direction. ${ }^{30}$ Scenes of herdsmen carrying calves, with the cows approaching their young ones are familiar in Egyptian art, ${ }^{31}$ but in the tomb of Mery-aa at El-Hagarsa, probably

27 See: Blackman 1953; Kanawati, Evans 2014b; Kanawati et al. 2015.

28 Blackman 1924: P1. 16; Kanawati 2012: Pl. 75(b).

${ }^{29}$ Kanawati 1993: 57. The tomb was earlier dated by Petrie to the Sixth Dynasty (Petrie 1908: 2), and Harpur suggests a date during the reign of Pepy II or in the Eighth Dynasty (Harpur 1987: 281 [676]).

${ }^{30}$ Kanawati 1993: 57, P1. 43. This same posture, but for an ox, is found again in the tomb of Nikauisesi at Saqqara (dated to the beginning of the Sixth Dynasty): Kanawati, Abder-Raziq 2000: P1. 49. For comments, see: Evans 2010: 156, Fig. 10-8(SB22).

31 For examples from the Old Kingdom, see: Wild 1953: P1. 114; Simpson 1980: Fig. 30; Kanawati, McFarlane 1993: P1. 51; Altenmüller 1998: Pls 17(a), 39; Brovarski 2000: Figs 96-97; Harpur, Scremin 2006: Fig. 7. For Middle Kingdom examples, see: Blackman 1914: P1. 11; 1915: Pl. 7; Kanawati, Evans 2017: Pls 76, 85; Newberry 1893a: P1. 30; Kanawati, Evans 2014a: P1. 126. 
from the Eighth Dynasty, ${ }^{32}$ this same motherly behaviour is depicted twice for donkeys. ${ }^{33}$ A motherly attitude appears also in the above-mentioned scene as well as in the neighbouring tomb of Wahi (Eighth Dynasty), ${ }^{34}$ where a young donkey faces its mother while she bends her head down to reach it. ${ }^{35}$

The interest in representing different aspects of the characteristic features of donkeys takes on new dimensions towards the end of the Old Kingdom and the succeeding period. Thus in the tombs of Ankhtifi and Sobekhotep at Moalla, dated to the Eighth or the Ninth Dynasty, ${ }^{36}$ a small donkey is shown approaching its mother ${ }^{37}$ and the chestnut ${ }^{38}$ and the shoulder and dorsal stripes of the animals are well defined. ${ }^{39}$ In one instance a playful dog is seen scratching the forehead of a donkey, ${ }^{40}$ and in two others, donkeys are rolling over, presumably in an attempt to scratch their backs. ${ }^{41}$ More importantly and very curiously donkeys are shown in agricultural activities, pulling the plough instead of oxen. ${ }^{42}$

An unusual position for the chestnut is found in the Eleventh Dynasty tomb of Djar at Thebes, where it is drawn at the animal's knee level rather than on the upper part of the forelegs. ${ }^{43}$ As the chestnuts are found on the inner side of the upper part of both forelegs, only one could physically be seen by the viewer, and this fact was correctly observed by the artists in their two dimensional art; thus the chestnut is shown on one of the forelegs, i.e., the farther one from the viewer. However, in Djar's tomb the artist drew the chestnut on both forelegs, thus he drew what he knew rather than what he saw.

While a scene showing donkeys in the tomb of Djehutihotep (Twelfth Dynasty) ${ }^{44}$ at El-Bersha is fragmentary, the shoulder and dorsal stripes of the animals are clearly marked, but not the chestnuts or at least these are not recorded in the available line drawing. ${ }^{45}$ Special attention was given at Beni Hassan to the representation of different aspects of the lives of donkeys. A herdsman is shown on the south wall of the tomb of Baqet III (Eleventh Dynasty), ${ }^{46}$ carrying a foal over his shoulder, with the mother following and trying to reach to its young one (Fig. 4a). The depiction of a herdsman carrying a young animal was common in the Old Kingdom, but only with cattle. In the scene of Baqet III's tomb

32 Kanawati 1995: 29. Petrie dates the tomb to the Sixth Dynasty (Petrie 1908: 2); for a date in the Ninth Dynasty, see: Simpson 1974:100. Fischer also dates the tomb to the Heracleopolitan Period (Fischer 1968: 30, n. 574).

33 Kanawati 1995: Pls 37, 39-40.

34 Kanawati 1995: 13.

35 Kanawati 1995: Pls 28, 31.

36 Vandier 1950: 13f.; Gomaà 1980: 30ff.; Kanawati, McFarlane 1992: 157ff.; Spanel 1984: 87-94.

37 Vandier 1950: P1. 42.

38 Vandier 1950: Pls 11, 36.

39 Vandier 1950: Pls 34, 36, 38.

40 Vandier 1950: P1. 34.

41 Vandier 1950: Pls 9, 38.

42 Vandier 1950: P1. 32.

43 Winlock 1942: Pl. 17; Smith 1965: Pl. 58B.

${ }^{44}$ Newberry 1895: 6.

45 Newberry 1895: P1. 31.

${ }^{46}$ Newberry 1893b: 6-7; Kanawati, Evans 2018: 16. For dating to the Twelfth Dynasty, see: Favry 2005: 39. 
we also see a foal suckling from its mother (Fig. 4a), ${ }^{47}$ while another goes in the opposite direction, with the mother following and a herdsman forcing them to rejoin the herd using his stick. ${ }^{48}$ On the same wall, the usual scenes of the mating of oxen, including sniffing and mounting, are shown, yet here such activities are depicted for the donkeys. Not only has a male mounted a female ${ }^{49}$ but the usual sexual urge of the male donkey is demonstrated by a clear erection. ${ }^{50}$ The artist of Baqet III showed his familiarity with the physical appearance of the donkeys by depicting the shoulder and dorsal stripes and the chestnut on the upper parts of their forelegs. ${ }^{51}$

The artist of the tomb of Khety (Eleventh Dynsaty) $)^{52}$ of Beni Hassan also represented mating donkeys and showed at least one foal. However, the scene here appears to be in the pasture rather than back in the province and before the nomarch. ${ }^{53}$ In a scene of transporting the harvest, the artist clearly observed the characteristic physical features of the donkeys, namely the shoulder and dorsal stripes as well as the chestnuts on the forelegs. ${ }^{54}$

As is the case in the tomb of Baqet III, motherhood is emphasised in the tomb of Amenemhat (early Twelfth Dynasty), ${ }^{55}$ with a herdsman carrying a foal to entice the mother to follow and another foal is suckling from its mother. ${ }^{56}$ On the west wall of the same tomb a scene depicts agricultural pursuits, where the harvest has been unloaded from the back of a donkey onto the threshing floor. The markings on the animal clearly show the stripes on its shoulder and the chestnut on the inside, upper part of its foreleg. ${ }^{57}$ Aspects of the donkeys' behaviour are clearly recorded in the neighbouring tomb of Khnumhotep II, ${ }^{58}$ also from the Twelfth Dynasty, ${ }^{59}$ where a herdsman carries a foal with the mother following and trying to reach out to her young one, two donkeys are mating ${ }^{60}$ and, as seen in the tomb of Ankhtifi at Moalla, one animal is rolling over, presumably in an attempt to scratch its back (Fig. 4b).

47 For examples of suckling calves, see: Blackman 1915: P1. 7; Kanawati 1981: Fig. 20; Kanawati, McFarlane 1993: Pl. 33; Roth 1995: Pl. 156; Brovarski 2000: Fig 42. For suckling goats, see: Moussa, Altenmüller 1971: Pls 4, 18; Lashien 2013: Pls 81, 83; and for suckling desert animals, see: Roth 1995: P1. 168; Badawy 1978: Fig. 35; Kanawati, Hassan 1997: P1. 43(b).

48 Newberry 1893b: P1. 7; Kanawati, Evans 2018: P1. 62.

49 See Fig. 4a. This detail is not very clear in Newberry's record; see: Kanawati, Evans 2018: P1. 62.

${ }^{50}$ For the sexual behaviour of the donkeys, see: Power 2004: 132ff.

51 See Fig. 4a and Kanawati, Evans 2018: P1. 62.

52 Newberry 1893b: 53.

53 Newberry 1893b: P1. 12; Kanawati, Woods 2010: Photograph 177.

54 These details are clear in: Kanawati, Woods 2010: Photograph 178.

55 Newberry 1893b: 13; Kanawati, Evans 2016: 20.

56 Newberry 1893a: Pl. 13; Kanawati, Evans 2016: P1. 95.

57 These details are not visible in Newberry 1893a: Pl. 11, but the re-recording of the figure confirms their presence; see: Kanawati, Evans 2016: P1. 92.

58 Newberry 1893a: P1. 30; Kanawati, Woods 2010: Photograph 171; Kanawati, Evans 2014a: P1. 125.

59 Newberry 1893a: 41; Kanawati, Evans 2014a: 24-25.

${ }^{60}$ Curiously the mating is recorded in the cases of goats and donkeys, but not in those of oxen and sheep; see: Kanawati, Evans 2014a: Pls 125-126. 

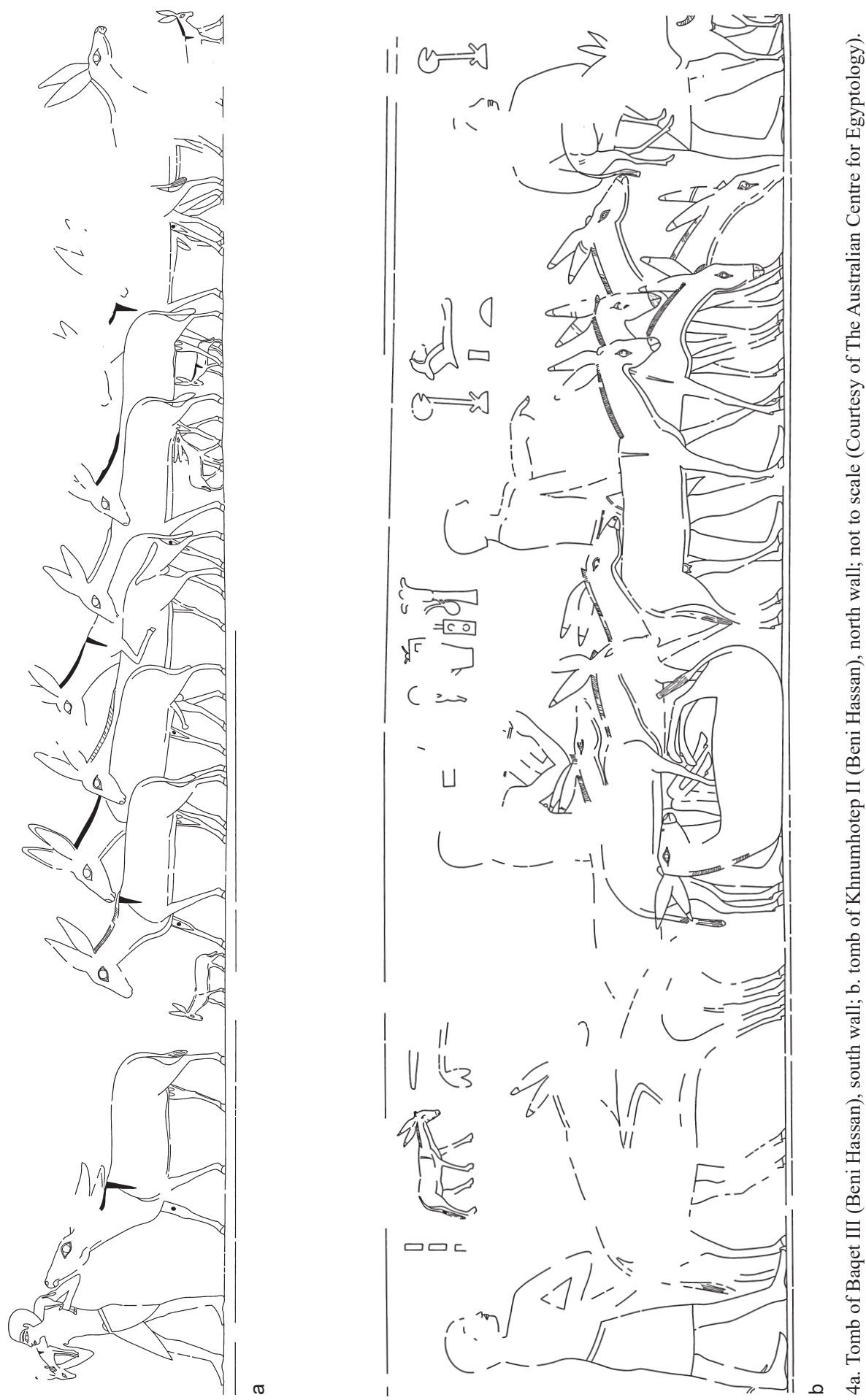


\section{DONKEYS IN LIVESTOCK COUNTS}

Until the end of the Old Kingdom, scenes of animal husbandry were focused on large and small cattle and to a lesser extent on desert animals, although more importance seems to have gradually been given to the latter as the Old Kingdom progressed. The importance of cattle becomes apparent in references to cattle count. Pepyankh the middle (early Pepy II) of Meir, who held the office of 'overseer of Upper Egypt in the middle provinces', ${ }^{61}$ and was accordingly responsible for assessing taxes ${ }^{62}$ in the most fertile and productive region of the country, ${ }^{63}$ referred to his undertaking of the animal 'count'. He says: irt irw $n$ mnmnt 'wt n sp3wt hrywt-ib m33 iw3 wnd w, 'Making the count of the cattle and the small animals in the middle provinces, and viewing the oxen and goats' ${ }^{64}$ His grandson, Pepyankh the black, whose responsibilities as 'overseer of Upper Egypt' were, unlike his grandfather, restricted to the $14^{\text {th }}$ nome, made a similar statement, although the figures he recorded are understandably smaller. ${ }^{65}$ Djau of the $12^{\text {th }}$ nome of Upper Egypt also depicts the large and small animals in his possession and refers to making a count. ${ }^{66}$ Many other provincial governors refer to the large numbers of cattle they possessed or cared for, ${ }^{67}$ although frequently omitting the donkeys. The emphasis on cattle, as an important part of the country's wealth, may be judged by the fact that the 'count' of these animals, whether it was undertaken annually or biannually, ${ }^{68}$ was so regular that it was used throughout Egyptian history in the dating of the specific events and is considered one of our basic criteria for establishing the Egyptian chronology.

Since donkeys, in contrast to large and small cattle, did not constitute a stereotyped source of meat or milk, they were presumably a less important 'countable' part of the state's wealth. On the other hand they were essential and useful animals in Egyptian agricultural society, and therefore representations of donkeys were mostly restricted to scenes related to the agricultural pursuits. Nevertheless, they may have represented a significant part of certain individuals' wealth. Examples of recording the numbers of donkeys are found in some tombs throughout the period under investigation. An early example of the 'count' where donkeys appear is found in the tomb of the dwarf Seneb at Giza, dated to the late Fourth to early Fifth Dynasty. ${ }^{69}$ On the right wall of a niche containing Seneb's false door, the tomb owner is shown seated in a kiosk and receiving the accounts from one of his scribes, while another scribe is recording the number of animals declared by the

${ }^{61}$ Blackman 1924: Pl. 16; Kanawati 2012: Pl. 75(b).

${ }^{62}$ For the responsibility of the 'overseer of Upper Egypt' as tax assessor/collector, see: Martin-Pardey 1976: $152 \mathrm{ff}$.

${ }^{63}$ For a discussion on the middle provinces and the most fertile region in Egypt, see: Lashien 2017: 118ff.

${ }^{64}$ Blackman 1924: Pl. 4A:1; Kanawati 2012: 41, P1. 82.

${ }_{65}$ Blackman 1953: Pls 32, 41; Kanawati, Evans 2014b: Pls 82, 92.

${ }^{66}$ Davies 1902: Pl. 9; Kanawati 2013: Pls 61, 74.

${ }^{67}$ See, for example: Kanawati 1980: Fig. 14; 1981: Fig. 26.

${ }^{68}$ Kanawati 2000: 25ff.; Baud 2006: 144ff.; Verner 2008: $23 \mathrm{ff}$.

${ }^{69}$ The dating of the tomb of Seneb has been discussed by a number of scholars with conclusions ranging from the Fourth to the Sixth Dynasties. For a recent discussion of its date, see: Woods 2010: 301-331. 
head herdsmen. The different species of the counted animals are portrayed in the lower three successive registers, with the numbers of each inscribed. These are: (1) long-horned bulls, 10,015, females, 10,000; (2) male donkeys, 12,017, females, 10,200; (3) male sheep, 10,205 , females, $10,103 .{ }^{70}$ Qereri of Akhmim, who left a biography stating that he served as inspector of priests and royal chamberlain at the time of Meryre/Pepy I, proudly recorded his possessions by saying: iw ir.n(.i) hmwt bnnt iw rdi.n.sn '3 200, '(I) acquired a (herd) of she-asses, and they produced 200 asses'.$^{71}$ It is noteworthy that no other animals are included in Qereri's wealth.

With the progress of the Old Kingdom more attention to the inclusion of donkeys among the counted animals is evident. Thus in the tomb of Pepyankh the black of Meir, dated to the end of the Sixth Dynasty, ${ }^{72}$ donkeys are included with oxen, goats and sheep presented to the tomb owner, with figures giving the numbers of each species, although these are not always preserved. ${ }^{73}$ In this scene, the caption says $m 33$ irt irw $m$ tn $n w k 3 w^{`} w t n b t$, 'viewing the making of the count of the numbers of bulls and all small cattle', and the animals are placed in superposed registers, with the bottom three registers reserved for oxen, the fourth register for goats and the top register for donkeys and sheep, where the figures 20,302 are recorded above the female donkeys. Furthermore, Pepyankh the black is depicted in room $\mathrm{F}$ inspecting the count of his livestock, where a vertical column of inscription states

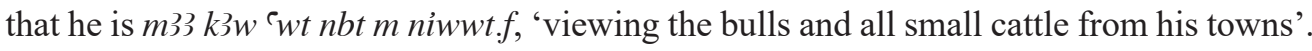
While no donkeys are illustrated among the animals, it is interesting that the word for small cattle, ${ }^{\top} w t$, includes a sheep, a goat and a donkey, which shows that donkeys were among the counted small animals. ${ }^{74}$ From almost the same period the animals presented to Djau of Deir el-Gebrawi are also depicted in three registers, but with oxen placed in the top one, followed by the sheep and finally goats and donkeys in the bottom register. ${ }^{75}$

Two tombs at El-Hagarsa preserve interesting representations of donkeys. In the tomb of Mery (second half of Pepy II's reign), the tomb owner appears in a viewing scene, the caption describing the scene reads: $m 33 k 3 w{ }^{\top} w t{ }^{\top} 3 w$, 'viewing the bulls, small cattle and donkeys', and it is interesting that while no count is given to the bulls/oxen, the figure 12,000 is written above the small cattle and 20,000 above the donkeys. ${ }^{76}$ In the other tomb at El-Hagarsa, that of Mery-aa (probably Eighth Dynasty), the owner is viewing the animals, which are arranged into five registers, the top two of which are reserved for oxen, the third

70 Junker 1941: Figs 18-19, Pl. 6(b). It is noticeable that the numbers of males are larger than those of the females in case of all kinds of the animals. This is curious as females are generally kept for reproduction.

71 Kanawati 1986: 48-49, Fig. 20(b-c).

72 For the dating of Pepyankh the black's tomb, see: Harpur 1987: 280 [649]; Kanawati, McFarlane 1992: 300; Kanawati 2010: 217; Kanawati, Evans 2014b: 18; Lashien 2017: 221.

73 The number of the donkeys is not recorded in Blackman's publication (Blackman 1953: Pl. 32), but it is included in the recent re-recording of the tomb by the Australian Centre for Egyptology; see: Kanawati, Evans 2014b: 54, P1. 92.

74 Blackman 1953: Pl. 41; Kanawati, Evans 2014b: P1. 82.

75 Davies 1902: Pl. 8; Kanawati 2013: Pls 63, 76. For the tomb's dating, see: Harpur 1987: 280 [647]; Kanawati, McFarlane 1992: 2, 299; Kanawati 2013: 23f.; Lashien 2017: 58-65.

76 Kanawati 1993: 60, P1. 43; Petrie 1908: 4, P1. 12. 
register for the small cattle and the bottom two registers for donkeys. The allocation of two registers for donkeys is significant and perhaps emphasises their importance at least at that time. In one register they are depicted performing their usual agricultural activities, while in the other they are being presented to the tomb owner. A vertical line of inscription before the owner explains his action as: $m 33$ irw in h33ty-` smr w'ty hry-hbt im3hw Mry-`3 $m$ ǐst.f $\underline{d} s . f m w n-m 3^{\top} n n\left[{ }^{c} b\right]^{\complement} \mathrm{im}$, "viewing the cattle count by the count, the sole companion, the lector priest, the honoured one, Mery-aa, from his own property, in reality. There is no boasting therein', Mery-aa informs us that the counted animals are his 'own property'. His emphasis on the absence of boasting may refer to his ownership of the animals and or to their large numbers. While the caption above the oxen reads: irw $n f r n k 3 w$, 'a good count of oxen', and that above the small cattle reads: irw nfr $n$ ' $w t$, 'a good count of small cattle', the caption above the donkeys specifically mentions: irw $n f r n$ ` $w$ ` 33 wrt, 'a good count of a great many asses'. ${ }^{77}$ We have no reason to doubt the truth of Mery-aa's claim.

A similar case to that of Mery-aa is found in the tomb of Ip at El-Saff, who may not be far removed in time from Mery-aa. ${ }^{78}$ In a scene of presentation of the count, the tomb owner leans on his staff in a relaxed manner with the space before him divided into four registers. The top register is occupied by the figures of a scribe, followed by a herdsman encouraging a young calf to proceed so the herd of oxen will follow. The second register depicts an almost identical scene to the one above, except that the animals, both young and old, are in this case donkeys. The third and fourth registers are less well preserved, but probably showed the bringing of different desert animals. The caption describing the scene reads: $m 33$ ip ' $w y h s[b][h k 3 w]$......, 'viewing the reckoning of production and the rendering of accounts of the [managers]...... . ${ }^{79}$ The order in which the different animals are placed in the successive registers in this scene may suggest that donkeys were second in importance after the large cattle, but before the desert animals. We also notice a stress on the counting of the young donkeys among the animal production. On the west face of Middle Kingdom stelae from Serabit el-Khadim in Sinai, where the owner is depicted riding a donkey, the number of 200 donkeys is recorded among gifts brought to the temple of Hathor. ${ }^{80}$

In the tomb of Baqet III (Eleventh Dynasty) at Beni Hassan, the tomb owner is shown inspecting the various activities in his province, including animal husbandry, making pottery, manufacturing of staffs and metalwork. Both the second and third registers, which are located in an advantageous viewpoint for Baqet, contain the bringing of animals and the recording of their numbers by scribes. While the second register is reserved for the bringing of oxen, the third register shows donkeys brought to the count. ${ }^{81}$ Scribes are seated in the latter register receiving reports from the heads of herdsmen who are led by policemen holding batons. Punishments are being inflicted, curiously on men and women, young and old. The reporting is probably concerned with the number of donkeys, perhaps

\footnotetext{
77 Petrie 1908: 17, P1. 9; Kanawati 1995: 35-36, Figs 37-40.

78 Fischer prefers a date in the Eleventh Dynasty (Fischer 1996: 29-32).

79 Fischer 1996: 19, Fig. 7, Pls 5, G.

${ }^{80}$ Gardiner, Peet 1952: P1. 37; 1955: 114.

${ }^{81}$ Newberry 1893b: P1. 7; Kanawati, Evans 2018: P1. 62; Kanawati, Woods 2010: Photographs $172-175$.
} 
after their return from a season in the pastures. The artist demonstrated the increasing number of donkeys by depicting five foals among the herd. ${ }^{82}$

Also at Beni Hassan, the tomb of Amenemhat (early Twelfth Dynasty) portrays the owner on the north wall standing with a vertical line in front of him describing his action as: $m 33$ irt irw mnmnt in h3ty- 'Imn $m 3{ }^{\mathrm{C}}-\mathrm{hrw} n \mathrm{n}$ im 3 h, 'viewing the undertaking of the count of cattle by the count, Amen, the justified, possessor of veneration'. It is notable that the word for cattle mnmnt has the determinative of three species of animals: an ox, a goat and a donkey. The space opposite the figure of Amenemhat is divided into five registers. While the first and third registers are dominated by figures of offering bearers and officials, the second register is reserved for the representation of oxen, the fourth register for the donkeys and the fifth for the goats. Scribes are represented in the fourth and fifth registers recording the numbers of each species, and herdsmen are brought before them, led by policemen, to render accounts. The scribe Baqet, who held the title 'royal scribe', appears before the tomb owner presenting him with a document that states the numbers of these animals. ${ }^{83}$ The writing on the document is partly effaced, but the inclusion of the donkeys in the count is certain. ${ }^{84}$

In the neighbouring tomb of Khnumhotep II (Twelfth Dynasty), the owner appears on the north wall receiving Asiatic settlers with their gifts as well as viewing reports from his officials on the wealth of the province. It is interesting that the caption written above him and explaining his actions reads: $m 33$ irt irw mnmnt nbt inw in n.f $m$ niwwt.f $3 h w t . f n t(y w)$

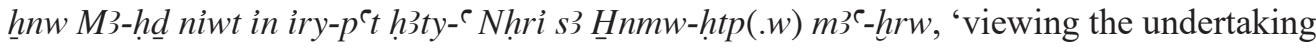
of the count of all the cattle and the gifts which are brought for him from his towns and his fields which are inside the Oryx nome and (his) city ${ }^{85}$ by the hereditary prince, the count Nehri's son, Khnumhotep, the justified' ${ }^{86}$ As in the case of Amenemhat, the word for cattle mnmnt has the determinative of three species of animals: an ox, a goat and a donkey. These animals are placed in the bottom register, ${ }^{87}$ where the scribes recording the count sit to the right, receiving the heads of the herdsmen accompanied, in a submissive manner, by policemen. The herds of animals are arranged in the following order: oxen, goats, donkeys and sheep. The herdsmen appear to be well organised, with hierarchical responsibilities. They also show professional specialisation, thus they are divided into herdsmen of oxen, of goats and more interestingly those of donkeys, and it is notable that in one instance a 'herdsman of donkeys' is depicted assisting in caring for oxen.

${ }^{82}$ On the same wall, in the second register, a number of calves are also depicted among the returning oxen (Newberry 1893b: Pl. 7; Kanawati, Evans 2018: Pl. 62).

${ }^{83}$ Newberry 1893a: Pls 13, 21(3); Kanawati, Evans 2016: Pls 95-96.

${ }^{84}$ Newberry 1893a: 32, Pl. 21(3).

${ }^{85}$ While the first mention of niwwt.f probably refers to his 'towns/funerary estates', the use of niwt $(. f)$ in the statement 'from his towns and fields inside the Oryx nome and (his) city' presumably indicates the city of Menaat Khufu, which Khnumhotep II governed. See his biography: Newberry 1893a: Pl. 25; Kanawati, Evans 2014a: 31-32, P1. 110.

${ }^{86}$ Newberry 1893a: Pl. 30; Kanawati, Evans 2014a: 44-45, Pls 124-126.

${ }^{87}$ Newberry 1893a: Pl. 30; Kanawati, Evans 2014a: 52-53, Pls 125-126. 


\section{CONCLUSIONS}

A survey of the daily life scenes in private tombs of the Old and Middle Kingdoms demonstrates the familiarity of artists, some more than others, with the physical and behavioural characteristics of the various animals and birds they represented. But the artist's interest in illustrating those characteristics varied from one animal to another, probably according to the extent of its significance in Egyptian society. An examination of wall scenes of the Old and Middle Kingdoms shows that the worth of donkeys to the Egyptians was gradually increasing. With the progress of the Old Kingdom and during the Middle Kingdom more attention to including donkeys among the counted animals is evident, particularly in the provinces; thus they are mentioned with oxen, goats, sheep and desert animals. Although donkeys were not considered as a part of food sources, their economic significance increased, probably due to their use in transporting products within and between different provinces. Beside the usual role of these animals in the rural transport, they must have also fulfilled an important role in the long-distance trade between Egypt and the neighbouring regions because of the growing trade traffic. The relative importance of donkeys varied from one individual to another; sometimes the animals are placed immediately after oxen and in one example they represent the only animal wealth the tomb owner recorded (Qereri of Akhmim). Herds of donkeys were sometimes very large, with Mery of El-Hagarsa claiming to possess 20,000 while Pepyankh the black of Meir recorded a number of 20,302 for female donkeys. At the end of the Sixth Dynasty donkeys became a part of 'small cattle', thus we see a donkey included in the determinative of the word ${ }^{\prime} w t$ in the tomb of Pepyankh the black at Meir, while in the Twelfth Dynasty, Amenemhat and Khnumhotep II of Beni Hassan recorded the word for cattle mnmnt in their tombs with the determinative of three species of animals: an ox, a goat and a donkey. Also at the same site herdsmen appear to show professional specialisation; herdsmen of oxen and others of goats and others still of donkeys.

While donkeys seem to have been gaining more value to Egyptians throughout the period under investigation, artists gradually showed more interest in representing the animal's physical appearance, reproduction, breeding and life aspects. The depictions of donkeys during most of the Old Kingdom focused on their participation in agricultural pursuits with rare attention to the animal's characteristics or life cycle. Artists occasionally represented the 'chestnut' on the inner side of the animal's foreleg and/or the shoulder and dorsal stripes, although the 'chestnut' is a main physical characteristic feature of all donkeys species, while the existence of the shoulder marking varies. Artists also represented farmers controlling unyielding donkeys by holding them by one leg and one ear. In one instance the black stripes on the legs of the rare Somali wild ass were clearly indicated. One wonders if in addition to breeding domestic asses the Egyptians imported a new, stronger species of Somali ass, which is so far attested only in the Sixth Dynasty tomb of Pepyankh the middle at Meir. Its absence elsewhere may indicate that their breeding was unsuccessful, but it may equally be that their characteristic markings have disappeared in some scenes. At the end of the Old Kingdom we see donkeys pulling plough instead of oxen in a very 
curious instance, and in another a playful dog is scratching the forehead of a donkey. Representation of various aspects of this animal's life became more conspicuous as time progressed. Thus we see mating donkeys, a foal walking in front of its mother or carried by a herdsman with the mother following and reaching toward its young one, a foal suckling from its mother and a donkey rolling over to scratch its back.

\section{Acknowledgements}

This paper was presented in the 7th conference of the Old Kingdom Art and Archaeology held in Milan, Università degli Studi di Milano (2017). I would like to express my sincere thanks for Dr Linda Evans who edited the article with a critical eye and made many useful suggestions, and also my special thanks go to the director of the Australian Centre for Egyptology (Macquarie University), Professor Naguib Kanawati for his permission to publish the figures used in this work.

\section{References}

All about Donkeys: http://www.lovelongears.com/about_donkeys2.html (accessed January 22, 2020)

Altenmüller, H. 1998: Die Wanddarstellungen im Grab des Mehu in Saqqara, ArchVer 42, Mainz a/Rhein

Badawy, A. 1978: The Tomb of Nyhetep-Ptah at Giza and the Tomb of 'Ankhm'ahor at Saqqara, University of California Publications: Occasional Papers 11, Berkeley

Baud, M. 2006: The relative chronology of Dynasties 6 and 8, [in:] Hornung, E., Krauss, R., Warburton, D.A. (Eds), Ancient Egyptian Chronology, HbOr 83, Leiden-Boston, $144-158$

Blackman, A.M. 1914: The Rock Tombs of Meir, Part I: The Tomb-Chapel of Ukh-Hotp's Son Senbi, ASEg 22, London

Blackman, A.M. 1915: The Rock Tombs of Meir, Part II: The Tomb-Chapel of Senbi's Son Ukh-Hotp (B, No. 2), ASEg 23, London

Blackman, A.M. 1924: The Rock Tombs of Meir, Part IV: The Tomb-Chapel of Pepironkh the Middle Son of Sebkhotpe and Pekhernefert, ASEg 25, London

Blackman, A.M. 1953: The Rock Tombs of Meir, Part V: The Tomb-Chapels A, No. 1 (That of Ni-'Ankh-Pepi the Black), A, No. 2 (That of Pepi`onkh with the 'Good Name' of Heny the Black), A, No. 4 (That of Hepi the Black), D, No. 1 (That of Pepi), and E, Nos 1-4 (Those of Meniu, Nenki, Pepi ${ }^{\circ}$ onkh and Tjetu), ASEg 28, London

Blench, R. 2013: Wild asses and donkeys in Africa: interdisciplinary evidence for their biogeography, history and current use. Revised and updated version of a paper presented at SOAS, $9^{\text {th }}$ May 2012, https://www.academia.edu/4807849/Wild_asses and_donkeys_in_Africa_interdisciplinary_evidence_for_their_biogeoagraphy history_and_current_use?email_work_card=view-paper (accessed April 27, 2020) 
Brovarski, E. 2000: The Senedjemib Complex, Part 1: The Mastabas of Senedjemib Inti (G2370), Khnumenti (G2374) and Senedjemib Mehi (G2378), Giza Mastabas 7, Boston

Closse, K. 1998: Les ânes dans l'Égypte ancienne, Anthropozoologica 27, 27-39

Clutton-Brock, J. 1992: Horse Power. A History of the Horse and the Donkey in Human Societies, Cambridge

Clutton-Brock, J. 1999: A Natural History of Domesticated Mammals, Cambridge

Clutton-Brock, J. 2012: Animals as Domesticated. A World View through History, Michigan

Davies, N. de G. 1902: The Rock Tombs of Deir el-Gebrâwi, Part II: Tomb of Zau and Tombs of the Northern Group, ASEg 12, London

Duell, P. 1938: The Mastaba of Mereruka, Part II: Chamber A 11-13, Doorjambs and Inscriptions of Chambers A 1-21, Tomb Chamber, and Exterior, OIP 39, Chicago

Edel, E., Wenig, S. 1974: Die Jahreszeitenreliefs aus dem Sonnenheiligtum des Königs Ne-user-Re, $M \ddot{A} S B$ VII, Berlin

Evans, J.W., Borton, A., Hintz, H., Van Vleck, L.D. 1990: The Horse, New York

Evans, L. 2010: Animal Behaviour in Egyptian Art: Representations of the Natural World in Memphite Tomb Scenes, ACE-Stud. 9, Oxford

Favry, N. 2005: Le nomarque sous le règne de Sésostris ${ }^{\mathrm{er}}$, Les institutions dans l'Égypte ancienne 1, Paris

Fischer, H.G. 1968: Dendera in the Third Millennium B.C. Down to the Theban Domination of Upper Egypt, New York

Fischer, H.G. 1996: The Tomb of Ip at El Saff, New York

Gardiner, A.H., Peet, T.E. 1952: The Inscriptions of Sinai, Volume 1, MEES 36, London

Gardiner, A.H., Peet, T.E. 1955: The Inscriptions of Sinai, Volume 2, MEES 45, London

Gomaà, F. 1980: Ägypten während der Ersten Zwischenzeit, TAVO 27, Wiesbaden

Harpur, Y. 1987: Decoration in Egyptian Tombs of the Old Kingdom: Studies in Orientation and Scene Content, London-New York

Harpur, Y., Scremin, P. 2006: The Chapel of Kagemni: Scene Details, Egypt in Miniature 1, Oxford

Hassan, S. 1932: Excavations at Gîza I. 1929-1930, Oxford

Hassan, S. 1944: Excavations at Gîza V. 1933-1934, Cairo

Houlihan, P.F. 1986: The Birds of Ancient Egypt, The Natural History of Egypt 1, Warminster

Junker, H. 1941: Die Mastaba des Snb (Seneb) und die umliegenden Gräber, Gîza V, Akademie der Wissenschaften in Wien, Philosophisch-historische Klasse Denkschriften 71/2, Vienna-Leipzig

Junker, H. 1953: Der Friedhof südlich der Cheopspyramide, Ostteil, Gîza XI, Akademie der Wissenschaften in Wien, Philosophisch-historische Klasse Denkschriften 74/2, Vienna

Kanawati, N. 1980: The Rock Tombs of El-Hawawish, The Cemetery of Akhmim, Volume 1, Sydney

Kanawati, N. 1981: The Rock Tombs of El-Hawawish, The Cemetery of Akhmim, Volume 2, Sydney 
Kanawati, N. 1986: The Rock Tombs of El-Hawawish: The Cemetery of Akhmim, Volume 6, Sydney

Kanawati, N. 1993: The Tombs of El-Hagarsa, Volume 1, ACER 4, Sydney

Kanawati, N. 1995: The Tombs of El-Hagarsa, Volume 3, ACER 7, Sydney

Kanawati, N. 2000: A new h3t/rnpt-zp for Teti and its implication for Old Kingdom chronology, GöttMisz 177, 25-32

Kanawati, N. 2007: Mereruka and King Teti: The Power behind the Throne, Cairo

Kanawati, N. 2010: Chronology of the Old Kingdom Nobles of El-Qusiya revisited, [in:] Hawass, Z., Manuelian, P. Der, Hussein, R.B. (Eds), Perspectives on Ancient Egypt: Studies in Honor of Edward Brovarski, ASAE-Suppl. 40, Cairo, 207-220

Kanawati, N. 2012: The Cemetery of Meir, Volume 1: The Tomb of Pepyankh the Middle, ACER 31, Oxford

Kanawati, N. 2013: Deir El-Gebrawi, Volume 3: The Southern Cliff: The Tomb of Djau/Shemai and Djau, $A C E R$ 32, Oxford

Kanawati, N., Abder-Raziq, M. 2000: The Teti Cemetery at Saqqara, Volume 6: The Tomb of Nikauisesi, ACER 14, Warminster

Kanawati, N., Abder-Raziq, M. 2003: The Unis Cemetery at Saqqara, Volume 2: The Tombs of Iynefert and Ihy (reused by Idut), ACER 19, Oxford

Kanawati, N., Evans, L. 2014a: Beni Hassan, Volume 1: The Tomb of Khnumhotep II, ACER 36, Oxford

Kanawati, N., Evans, L. 2014b: The Cemetery of Meir, Volume 2: The Tomb of Pepyankh the Black, ACER 34, Oxford

Kanawati, N., Evans, L. 2016: Beni Hassan, Volume 3: The Tomb of Amenemhat, ACER 40, Oxford

Kanawati, N., Evans, L. 2017: The Cemetery of Meir, Volume 4: The Tombs of Senbi I and Wekhhotep I, ACER 41, Oxford

Kanawati, N., Evans, L. 2018: Beni Hassan, Volume 4: The Tomb of Baqet III, ACER 42, Oxford

Kanawati, N., Evans, L., Lashien, M., Mourad, A.-L., Senussi, A. 2015: The Cemetery of Meir, Volume 3: The Tomb of Niankhpepy the Black, ACER 38, Oxford

Kanawati, N., Hassan, A. 1997: The Teti Cemetery at Saqqara, Volume 2: The Tomb of Ankhmahor, ACER 9, Warminster

Kanawati, N., McFarlane, A. 1992: Akhmim in the Old Kingdom, Part I: Chronology and Administration, ACE-Stud. 2, Sydney

Kanawati, N., McFarlane, A. 1993: Deshasha, The Tombs of Inti, Shedu and Others, ACER 5, Sydney

Kanawati, N., Woods, A. 2010: Beni Hassan: Art and Daily Life in an Egyptian Province, Cairo

Kanawati, N., Woods, A., Shafik, S., Alexakis, E. 2011: Mereruka and his Family, Part III/2: The Tomb of Mereruka, ACER 30, Oxford

Lashien, M. 2013: The Chapel of Kahai and his Family: The Tombs of Nikaiankh I, Nikaiankh II and Kaihep, ACER 33, Oxford 
Lashien, M. 2017: The Nobles of El-Qusiya in the Sixth Dynasty: A Historical Study, Wallasey

Makowski, M. 2014: Terracotta Equid Figurines from Tell Arbid. New Evidence on Equids, their Equipment and Exploitation in North Mesopotamia during Third and First half of second Millennium BC, EtudTrav XXVII, 258-278

Martin-Pardey, E. 1976: Untersuchungen zur ägyptischen Provinzialverwaltung bis zum Ende des Alten Reiches, $H \ddot{A} B$ 1, Hildesheim

Mini Donkey Terms Glossary: https://minidonkeyuniversity.com/mini-donkey-terms-glossary/ (accessed January 22, 2020)

Mohr, H.T. 1943: The Mastaba of Hetep-Her-Akhti: Study on an Egyptian Tomb Chapel in the Museum of Antiquities Leiden, MVEOL 5, Leiden

Moussa, A., Altenmüller, H. 1971: The Tomb of Nefer and Ka-hay, Old Kingdom Tombs at the Causeway of King Unas at Saqqara, ArchVer 5, Mainz a/Rhein

Moussa, A., Altenmüller, H. 1977: Das Grab des Nianchchnum und Chnumhotep, ArchVer 21, Mainz a/Rhein

Newberry, P.E. 1893a: Beni Hasan, Part I, ASEg 1, London

Newberry, P.E. 1893b: Beni Hasan, Part II, ASEg 2, London

Newberry, P.E. 1895: El-Bersheh, Part I: The Tomb of Tehuti-Hetep, ASEg 3, London

Petrie, W.M.F. 1908: Athribis, BSAE 14, London

Power, R.K. 2004: Deconstructing, deciphering and dating the donkey in Old Kingdom wall painting and relief, $B A C E 15,131-151$

Roth, A.M. 1995: A Cemetery of Palace Attendants, Including G 2084-2099, G 2230-2231, and G 2240, Giza Mastabas 6, Boston

Simpson, W.K. 1974: Polygamy in Egypt in the Middle Kingdom?, JEA 60, 100-105

Simpson, W.K. 1980: Mastabas of the Western Cemetery, Part 1: Sekhemka, Tjetu I, Iasen, Penmeru, Hagy, Nefertjentet and Herunefer, Djaty, Tjetu II and Nemesti, Giza Mastabas 4, Boston

Smith, W.S. 1965: The Art and Architecture of Ancient Egypt, Harmondsworth

Spanel, D. 1984: The date of Ankhtifi of Mo'alla, GöttMisz 78, 87-94

Vandier, J. 1950: Mo'alla : La tombe d'Ankhtifi et la tombe de Sébekhotep, BiEtud 18, Le Caire

Verner, M. 2008: The system of dating in the Old Kingdom, [in:] Vymazalová, H., Bárta, M. (Eds), Chronology and Archaeology in Ancient Egypt (The Third Millennium B.C.), Prague, 23-43

Wild, H. 1953: Le tombeau de Ti, Fasc. II : La Chapelle (première partie), MIFAO 65/2, Le Caire

Wild, H. 1966: Le tombeau de Ti III. La Chapelle (deuxième partie), MIFAO 65/3, Le Caire Winlock, H.E. 1942: Excavations at Deir El Bahri: 1911-1931, New York

Woods, A. 2010: A date for the tomb of Seneb at Giza: revisited, [in:] Woods, A., McFarlane, A., Binder, S. (Eds), Egyptian Culture and Society: Studies in Honour of Naguib Kanawati, vol. 2, ASAE-Suppl. 38, Cairo, 301-331

Yilmaz, O. 2012: Domesticated Donkey, Ankara 


\section{ÉTUDES et TRAVAUX XXXIII / 2020}
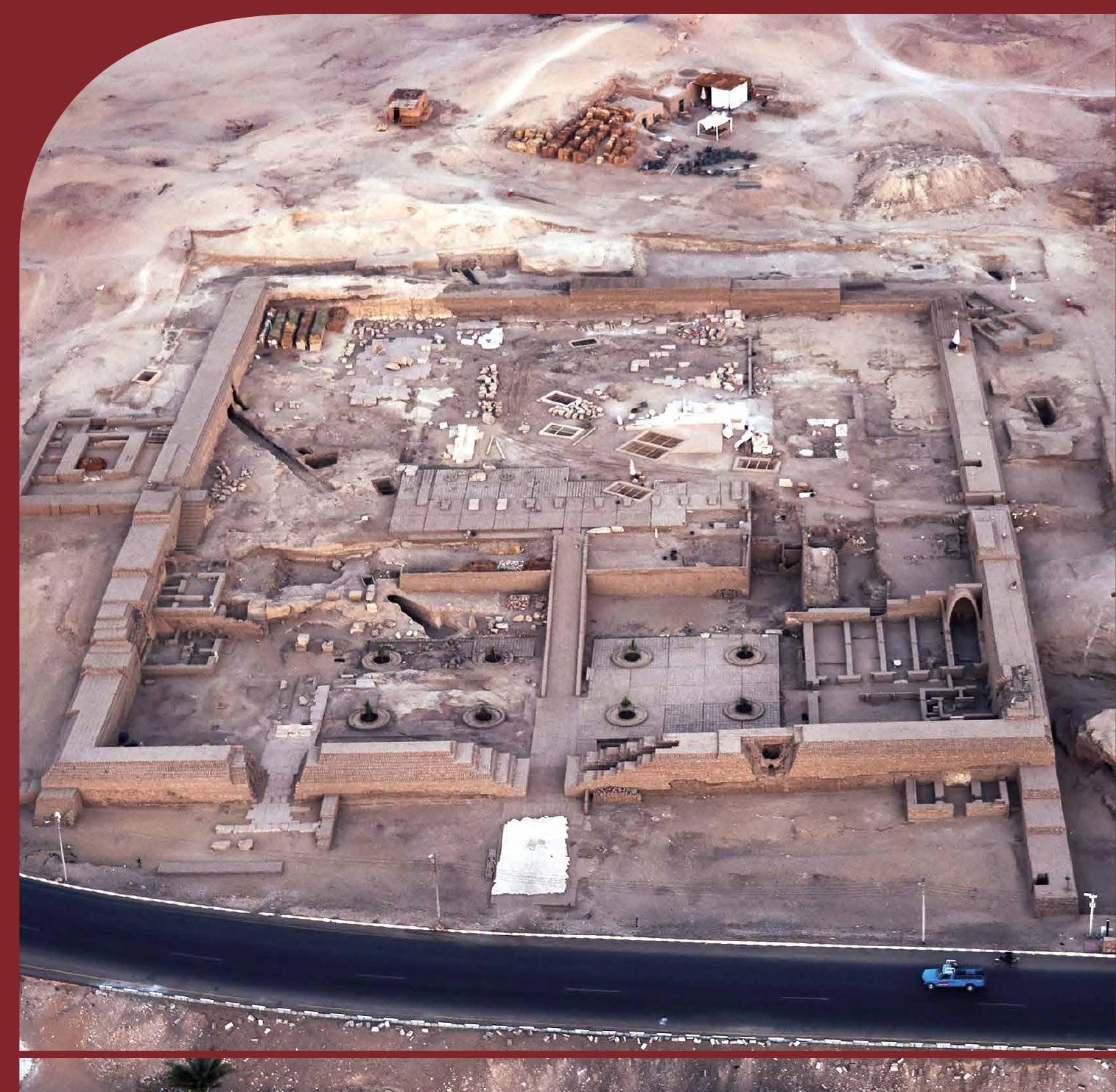

BOPIKSiO Institut des Cultures Mediterranéennes et Orientales IST PAN de l'Académie Polonáise des Sciences 


\title{
COMITÉ DE RÉDACTION SCIENTIFIQUE
}

Maciej Makowski - rédacteur en chef Jadwiga Iwaszczuk - rédacteur

Agnieszka Ryś - secrétaire de la rédaction

Ewa Laskowska-Kusztal - rédacteur thématique du volume

CONSEIL SCIENTIFIQUE DU JOURNAL

Michał Kobusiewicz (IAE PAN, Warszawa)

Ewa Laskowska-Kusztal (IMOC PAS, Warszawa)

Demetrios Michaelides (University of Cyprus, Nicosia)

Jean-Charles Moretti (IRAA-MOM, Université de Lyon 2/CNRS)

Dietrich Raue (Ägyptisches Museum der Universität Leipzig)

Paul Reynolds (ICREA, España)

Derek Welsby (British Museum, London)

COMITÉ SCIENTIFIQUE DE LECTURE

la liste des membres du comité est accessible en ligne sur

http://www.etudesettravaux.iksiopan.pl

\author{
RÉDACTION TECHNIQUE \\ Jadwiga Iwaszczuk \\ Maciej Makowski
}

REVUE DES TEXTES EN ANGLAIS

Jo Harper 
ÉTUDES et TRAVAUX XXXIII 
INSTYTUT KULTUR ŚRÓDZIEMNOMORSKICH I ORIENTALNYCH POLSKIEJ AKADEMII NAUK

\title{
STUDIA i PRACE
}

XXXIII

\author{
ROIKŚSiO \\ ESOPAN \\ WARSZAWA \\ 2020
}


INSTITUT DES CULTURES MÉDITERRANÉENNES ET ORIENTALES DE L'ACADÉMIE POLONAISE DES SCIENCES

\section{ÉTUDES et TRAVAUX}

XXXIII

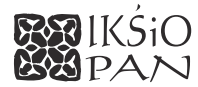

VARSOVIE

2020 
Publication scientifique financée dans le cadre du programme du Ministre de la Science et de l'Éducation Supérieure

« Programme National de Développement de l'Humanistique » pour les années 2016-2021 (projet no 3bH 150099 83)

\title{
NARODOWY PROGRAM ROZWOJU HUMANISTYKI
}

\author{
Copyright (C) \\ Instytut Kultur Śródziemnomorskich i Orientalnych PAN \\ et les Auteurs \\ Warszawa 2020
}
ISSN 2084-6762
(jusqu'en 2011 : 0079-3566)
e-ISSN 2449-9579
Version première en papier, imprimée en Pologne - 150 copies
Version électronique accessible sur
http://www.etudesettravaux.iksiopan.pl

Édition: Polskie Towarzystwo Historyczne et Wydawnictwo Neriton, Warszawa

Conception générale de la couverture : J. Iwaszczuk

Photographie de couverture : J. Pablo Moreira (C) Thutmosis III Temple Project

(Henket-ankh, le temple des Millions d'Années de Thoutmosis III, Louxor) 


\section{Table des matières}

Editorial (par Ewa Laskowska-Kusztal) ................................................................... 7

MirosŁaW BARWIK

Two Portraits of Senenmut in the Hatshepsut Temple at Deir el-Bahari

MirosŁaW BARWIK

New Prayers and Invocations to Hathor among Unpublished Dipinti

from the Thutmose III Temple at Deir el-Bahari

LiNDA CHAPON

The Decoration of the Columns and Pillars from the Henket-ankh of Thutmose III

(Western Thebes)

Abraham I. Fernández Pichel

Quelques blocs ptolémaïques inédits de la cour du IX pylône du domaine

d'Amon à Karnak

Amgad Joseph

The Stela of Haremwia, Chief of the Provisioning Sector of the Temple Workshop

(CG 34079 / JE 22011)

EWA JÓZEFOWICZ

Ramesside Inscriptions and Preparatory Sketches in the Western Wall of Portico

of Obelisks of Hatshepsut's Temple at Deir el-Bahari

Miral LASHiEN

Donkeys in the Old and Middle Kingdoms According to the Representations

and Livestock Counts from Private Tombs

AleKsandra Pawlikowska-Gwiazda

Christian Secondary Epigraphy in the Temple of Hatshepsut. Some New Remarks

KRZYSZTOF RADTKE

Square Grids in the Tomb of Akhethotep - Questions and Doubts

Myriam Seco Álvarez, JaVIER Martínez Babón

The Temple of Millions of Years of the Pharaoh Thutmose III (Luxor). An Update on the Research 